\title{
INTEGRATED MODEL OF PEACE EDUCATION BASED ON CONTEXTUAL ISLAMIC WASHATIYAH AT NURUL ISLAM ISLAMIC BOARDING SCHOOL JEMBER
}

\author{
Asnawan \\ IAI Al Falah As Sunniyyah Kencong Jember, Jawa Timur \\ email:asnawan@inaifas.ac.id
}

Abstract: Nurul Islam Islamic Boarding School as a peace boarding school having moderate character. When radicalism, extremism, and terrorism threaten world peace, the schools consistently campaign for peace. Therefore, the research focuses on peace education planning, implementation, and implication on students' behavior and attitude to find out a planning, implementation, and implication model of peace education. The research is a qualitative study using a multiple case study approach. The informants were chosen using a purposive sampling technique. The findings of the research are: Peace education planning in Nurul Islam Islamic Boarding School refers to vision, mission, institutional philosophy, Islam washatiyah, started with the need analysis of times, society, and students and by considering the suggestion of education users formulated by the educational institution. Peace education implementation employs an adaptation of religious text material using moderation approach, Islamic method and universal method, website supporting media containing digital washatiyah implemented informal institution integrated with ahlussunah wa al-jamaā' ah teaching through inter curricular activities and intensive and doctrinal extracurricular activities. The peace education implication in Islamic boarding school builds students' polite and tolerant behavior, moderate and contextual perspective, positive image for the local, national and regional society and supports Islamic boarding school continuous transformation. 
الملخص: أعلن معهد نور الإسلام منذ بداية نشأتهما بأنهما معهد السلام الذي لها خصية

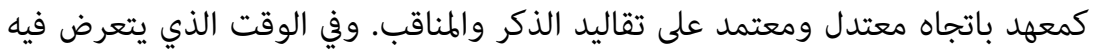

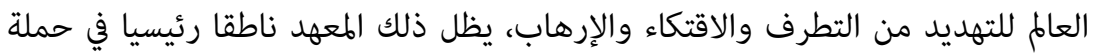

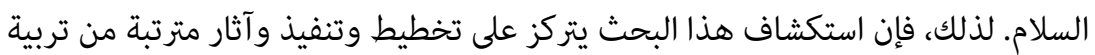

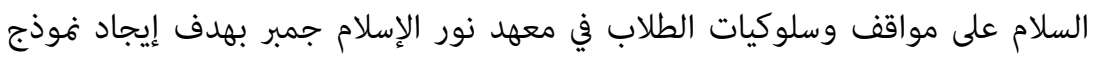

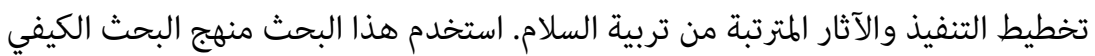

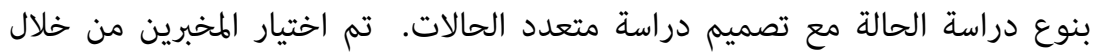

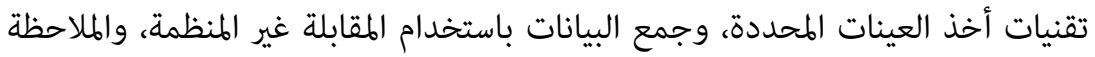

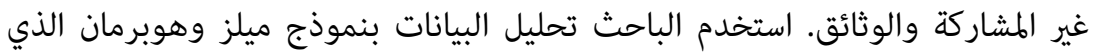

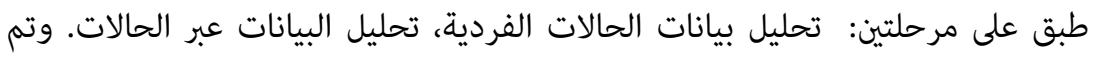

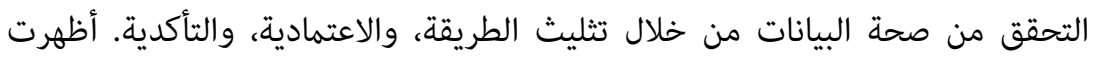

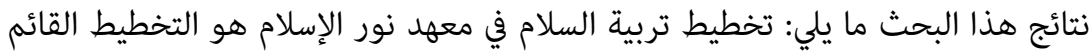

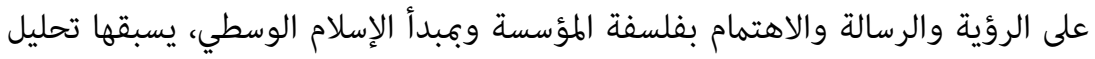

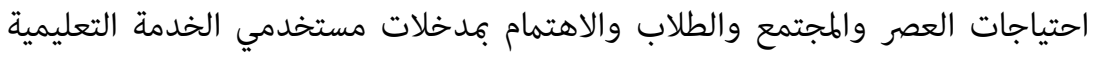

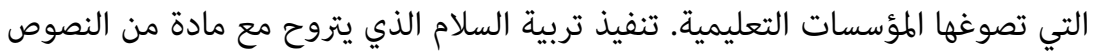

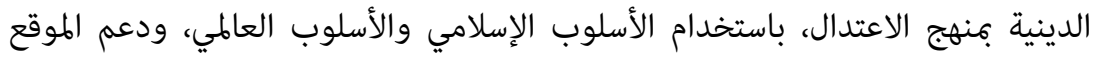

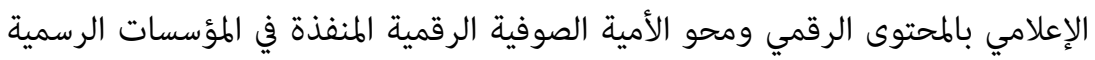

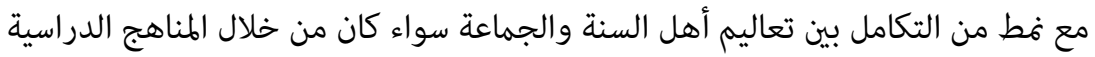

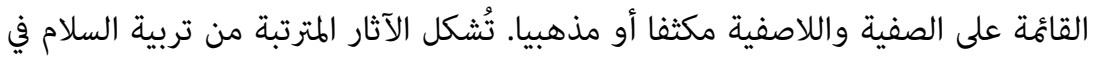

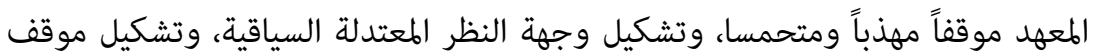

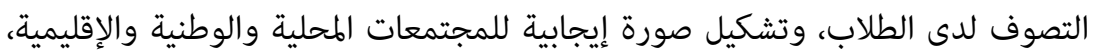
وتشجع التحول المؤسسي للمعهد بطريقة مستدامة.

Abstrak: Pesantren Nurul Islam memiliki karakter sebagai pesantren yang berhaluan moderat. Di saat perdamian dunia terancam oleh radikalisme, ektrimisme dan terorisme, pesantren tersebut tetap konsisten menjadi corong terdepan dalam kampanye perdamaian. Tulisan ini difokuskan pada perencanaan, pelaksanaan dan implikasi pendidikan perdamaian terhadap sikap dan prilaku santri dengan tujuan menemukan model perencanaan, pelaksanaan dan implikasi pendidikan perdamaian. Penelitian ini ialah penelitian kualitatif dengan pendekatan studi kasus yang dirancang menggunakan multikasus. Temuan dari 
penelitian ini adalah perencanaan pendidikan perdamaian di pesantren Nurul Islam adalah perencanaan berdasarkan pada visi, misi, memperhatikan filosofi kelembagaan, berprinsip Islam washatiyah, didahului oleh analisis kebutuhan zaman, masyarakat dan santri serta memperhatikan masukan dari pengguna jasa pendidikan yang dirumuskan oleh yayasan pendidikan. Pelaksanaan pendidikan perdamaian mengadapatasi materi dari teks keagamaan dengan pendekatan moderasi, menggunakan Islamic method dan universal method, media pendukung website berkonten digital washatiyah literacy yang dilaksanakan di lembaga formal dengan pola integrasi ajaran ahlussunah wa aljamā̄'ah baik melalui intra kurikuler maupun ekstrakurikuler secara intensif dan doktrinal, Implikasi pendidikan perdamaian pesantren membentuk sikap santun dan toleran, cara pandang moderat dan kontekstual, citra atau image positifbagi masyarakat lokal, nasional dan regional serta mendorong transformasi kelembagaan pesantren secara berkelanjutan.

Keywords: peace education, washatiyah, pesantren, Nurul Islam.

\section{INTRODUCTION}

Since its establishment, Islamic boarding schools have had a strong orientation towards strengthening, developing, and preserving the comprehending concept of ahl al-sunah wa al-jamä'ah as the strongest belief system in the world. The concept itself is believed to be able to provide a living tone as it was brought by the Prophet Muhammad known as Islam rahmat li al-'alamin. In addition to religious messages, Islam, as it is perceived from ahl al-sunah wa al-jam $\bar{a}^{\prime} a h$ perspective, carries several noble messages such as peace in the sense of both personal and universal peace which then has been misapprehended as enraged, ill-disposed, and bloodcurdling religion by a group of people who often act in the name of Islam. Education is an important component in efforts to penetrate and awareness transforming process of human behavior. ${ }^{1}$ However, they forget that

1 Eka Hendry, "Pengarus Utamaan Pendidikan Damai (Peaceful Education) Dalam Pendidikan Agama Islam (Solusi Alternatif Upaya Deradikalisasi Pandangan Agama)" At-Turats: Jurnal Pemikiran Pendidikan Islam, Vol. 9 No. 1 2015, 1. 
the fortification of religion, morals, and peace has long been taught in Islamic boarding schools like the Nurul Islam Islamic Boarding School of Jember which has implemented a peace education through a tranquility culture.

The Nurul Islam Islamic Boarding School of Jember was founded by KH. Muhyiddin Abdusshomad in 1981. This pesantren's establishment is strongly devoted through the penetrating efforts of $d a$ 'wah (Islamic preaching) carried out by Kyai Muhyiddin, as he is affectionately known. At that time, Kyai Muhyid "merely" facilitated the pesantren started by his father, KH. Abdussomad, on Jalan Mawar, Jember, namely the Darussalam Islamic Boarding School. Having the intention of expanding the reach of $d a$ 'wah, he, as the alumnus of the Sidogiri Islamic Boarding School, decided to move to Antirogo a year after ending his bachelor period. This pesantren is also known as NURIS. This abbreviation is inspired by the name of a famous action movie star named "Chuck Norris". The name "NORIS" or "NURIS" itself is very popular, people are easy to memorize it. This is part of a strategy to attract public interest. NURIS was agreed to later become the nickname of this Islamic boarding school which was then agreed by the public. ${ }^{2}$

The dynamics of Islamic education in Indonesia persist to experience changes both from learning practice, curriculum, yet Islamic education started from Islamic boarding schools. Several experts including Zamakhsyari Dhofier, ${ }^{3}$ Mastuhu, ${ }^{4}$ M. Arifin ${ }^{5}$ believe that it is an indigenous form of education in this country. However, the roots of Islamic boarding school education are inseparable from its past that Islamic educational institutions, also known as pesantren, originated from the educational model adopted from Kuttab education. ${ }^{6}$ The development of Islamic education in recent years has faced various theoretical and social problems, including the development of

2 Profile of the Nurul Islam Islamic Boarding School (NURIS) Jember 2020.

3 Zamakhsyari Dhofier, "Tradisi Pesantren, Studi Tentang Pandangan Hidup Kiai Jakarta: LP3ES” (Indonesia, 1990), 8.

4 Mastuhu, Dinamika Sistem Pendidikan Pesantren: Suatu Kajian Tentang Unsur Dan Nilai Sistem Pendidikan Pesantren (INIS, 1994), 6.

5 Mujamil Qomar, Pesantren: Dari Transformasi Metodologi Menuju Demokratisasi Institusi (Erlangga, 2009), 2.

${ }_{6}$ George Makdisi, Rise of Humanism in Classical Islam and the Christian West (Edinburgh University Press, 1990), 48. 
a monolithic and intolerant religious understanding that is developed from particular thoughts and ideologies so that Islamic boarding schools implementing radical ideology-based education will give birth to an intolerant attitude. For this matter, it can be seen that the realm of Islamic education and its institutions are not developed and established within a neutral area. ${ }^{7}$ For such reasons, it is believed that there will always be some kind of social constructs, cultural media, political intervention, and certain ideological bases that become patrons in educational institutions as well as academics.

A life of harmony, peace, and non-violence is the dream of all the citizens of the world, including those who live here in Indonesia. Unfortunately, we cannot always enjoy these ideal conditions together; conflicts between ethnic groups, organizations, and even between religions mostly occur even though it is not developed into a war, yet it means that we are still living in a situation of irreconcilable peace. ${ }^{8}$ The trend that has developed in the world of Islamic education lately is the development of radicalism phenomenon in religious thought within educational institutions, such as Islamic boarding schools, madrasas, and schools. This is demonstrated by cases of terrorism and violence which are generally carried out by people who are an alumnus of Islamic educational institutions who have a strong Islamic ideological motivation, where the ideology itself is also considered to be a religious doctrine. As it is known that the phenomenon of the close correlation between religious idealism and violence is potentially taking place within the memory of struggle and rivalry between religions confirming the ideological and political potential in society. ${ }^{9}$

\footnotetext{
Paulo Freire, The Naturality of Education Is one of the Fundamental Connotations of The Naïve Vision of Education, which can be interpreted that knowledge cannot be separated from interests, as well as education, education is always based on certain philosophies, theories, concepts, and worldviews. The practice of education cannot be separated from the philosophy that underlies it, whether it is pragmatic, conservative, liberal, progressive, liberating, or idealistic, thus education cannot be separated from the relations between knowledge, power, and ideology. M Agus Nuryatno, Mazhab Pendidikan Kritis: Menyingkap Relasi Pengetahuan, Politik, Dan Kekuasaan (Resist Book, 2008), 1-2.

8 Johan Galtung, we are still in a state of negative peace, there is no war yet we have not moved to a state of positive peace where the potential for conflict and war is no longer there.

9 Richard W Kaeuper, Holy Warriors: The Religious Ideology of Chivalry (University of Pennsylvania Press, 2009), 115-211.
} 
Throughout history, Islamic boarding schools have changed their functions according to the demands of the times which it is not only function as educational institutions but also as religious propaganda institutions. During the colonial period, Islamic boarding schools played an active role in opposing the infiltration of colonialism with uzlah, terminating interactions from outside influences. ${ }^{10}$ In line with human progress rationally, the thoughts of pesantren's leaders tend to develop an institution following the needs of the community by changing the methodological pattern of the education system, including the provision of formal (general) schools. This is as conveyed by Kuntowijoyo as quoted by Ghazali that "besides the development of education, pesantren's social activities include the fields of economy, technology, and ecology". ${ }^{11}$

Like others, Nurul Islam Islamic Boarding School Antirogo cannot be separated from the "royal system or throne". This particular Islamic boarding school has a synthetic style with a different developmental background, while the Islamic boarding school Nurul Islam Antirogo itself, since its establishment, has been progressing in a modern way. ${ }^{12}$ However, it still includes the Kitab Kuning learning produced by the ulama (Islamic scholar) in the past, especially those from the Middle East as their scientific locus. At this time, as we arrive within the era of competition, the Kyai or caretaker of the Islamic boarding school, $\mathrm{KH}$. Muhyiddin Abdusshomad fixes and develops Islamic boarding schools. However, it seems to have the same characteristics as other pesantren, it tends to be elitist and far from reality filled with social problems (poverty, dehumanization, and moral decadence) and it is too theocentric-oriented. This condition is exacerbated by the scientific problem of Islamic boarding schools experiencing gaps, alienation, and differentiation between religious erudition and the modern world. Tragically, graduates of Islamic boarding schools are

10 Mohammad Daud Ali and Habibah Daud, Lembaga-Lembaga Islam Di Indonesia, Cet. 1 (Jakarta: PT Raja Grafindo Persada, 1995), 46. The term uzlah was originally used in the world of Sufism for people who choose a place away from the crowds by isolating it from the hustle and bustle of the city atmosphere.

11 M Bahri Ghazali, Pesantren Berwawasan Lingkungan (Prasasti, 2002), 41.

12 Islamic boarding schools have incorporated technology in the curriculum and other rules. Apart from using the system, it also connects technology-based learning with the pesantren tradition. Look at Ronald Lukens-Bull, A Peaceful Jihad: Negotiating Identity and Modernity in Muslim Java (Springer, 2005), 120. 
unable to compete and they are not ready to compete with general graduates in the working world. Experiencing such problems, it is a certainty that Islamic boarding schools have a substantial burden of responsibility. ${ }^{13}$

Islamic boarding schools try to build graduates who can compete with graduates from other institutions through various training, which are unique in establishing unity amid diversity. The Nurul Islam Islamic Boarding School Antirogo itself carries out internal reconstruction in preparing graduates following the needs of the community by developing vocational education to support their skills. Thus, these two Islamic boarding schools have a dual task to be realized in producing ready-to-use graduates: first, to produce humans and Muslim communities who have faith and fear of Allah. So that the pesantren does not only function as a "divine institution" that is oriented to "heavenly interests", but it reproduces ulama' who have Islamic, scientific, and moral qualities to develop themselves and society. Second, to produce graduates of Islamic boarding schools as updated scientists of the times and the development of science and technology. Interestingly, the Kyai at the Islamic boarding school, in responding to this demand, did not uproot their traditions which were consistently instill the Islamic spirituality values with a culture of peace, mutual respect, the act of loving, fairness, justice, cooperation, and tolerance. For them, Islamic boarding schools are perceived as educational institutions which need to participate in the struggle for the development of science and technology-based on the spirit of integration with Islamic spiritual values. This standpoint is interesting to be investigated more deeply about the planning, implementation, and implications of peace education at the Nurul Islam I slamic boarding school Jember.

This study employs a descriptive qualitative approach/in-depth description. A case study principle is used as the type of research. This research was conducted at the Nurul Islam Islamic boarding school of Jember. A Case study research attempts to examine certain subjects and compare or contrast some of these subjects. The comparison

13 Malik Jamaluddin, Pemberdayaan Pesantren: Menuju Kemandirian Dan Profesionalisme Santri Dengan Metode Daurah Kebudayaan (Yogyakarta: Pustaka Pesantren Dan Yayasan Kantara Bangsa, 2005), xix-xxii. 
includes similarities and differences. ${ }^{14}$ The rules of the subjects being compared should be similar and comparable, because, each site can be the subject of an individual case study, and overall the study used a multi-case design. ${ }^{15}$ In collecting data, this research uses the method of observation, interviews, and documentation. Cross-case data analysis is intended as a process of comparing the findings obtained from each case as well as a process of integrating between cases. Checking the validity of data findings according to Lincoln and Guba as quoted by Ibrahim Bafadhal and Masykuri Bakri, namely through the degree of trust (credibility), transferability (transferability), dependability (dependability), and certainty (confirmability). ${ }^{16}$

\section{PEACE EDUCATION CONCEPT}

Peace originates from the word 'peace' which can be interpreted as the absence of war seen differently from the two dominant theories within International Relations, namely realism, and liberalism. Realism believes that peace is a negative thing and utopian characterized by the absence of war. ${ }^{17}$ The objective of peace education is to reduce or limit various human mental illnesses such as injustice, prejudice, intolerance, etc. ${ }^{18}$ The concept definition of peace education is still very much difficult to understand for peace education is developing rapidly causing some different definitions to emerge in the aspect of its conceptuality in which each definition cannot be considered to be right or wrong because each expert has their perspective in perceiving what peace education is all about. However, it is important to understand its basic concept before carrying it out within social life, both at school and outside of school. Each individual has the autonomy to determine

14 Abdul Wahab and Lies Amin Lestari, Menulis Karya Ilmiah (Surabaya: Airlangga University Press, 1999), 92.

15 Robert K Yin, Case Study Research: Design and Methods, Vol. 5 (Sage, 2008), 54.

16 Ibrahim Bafadal and Masykuri Bakri, Teknik Analisis Data Penelitian Kualitatif, Metodologi Penelitian Kualitatif: Tinjauan Teoritis Dan Praktis (Malang: Lemlit Unisma Dan Visipress, 20130, 185.

17 Robi Sugara, "Upaya Dan Kontribusi Indonesia Dalam Proses Perdamaian Di Afghanistan Melalui Bina-Damai," MUKADIMAH: Jurnal Pendidikan, Sejarah, Dan Ilmu-Ilmu Sosial 5, no. 1 (2021), 27-38.

18 Wahdan N Habiby and others, "Penyemaian Sikap Hidup Damai Di Sekolah: Tinjauan Pendidikan Perdamaian Dan Multi-Dimensi Kurikulum," Scholaria: Jurnal Pendidikan Dan Kebudayaan, 2020, 1-11. 
peace education that can reflect its values and context as Abebe Gbesso and Nyawalo state:

Peace education is a unifying and comprehensive concept that seeks to promote a holistic view of education. However, its relevance is inextricably part of and is highly dependent on contextual specificity. UNESCO literature states that Peace Educationists are more effective and meaningful when adopted according to the social and cultural context and needs of a country. It should be enriched by its cultural and spiritual values together with universal human values. ${ }^{19}$

Based on the above definition, it can be said that peace education is an educational format viewed holistically, which holistic education itself must be seen from the evolving context. Education is more meaningful and effective when it is following social, cultural, and national needs or goals. Peace education must be enriched by spiritual values and human values. While John Dewey defines peace education as:

Peace education as a curriculum which will make it more difficult for the flames of hatred and suspicion to sweep over this country in the future, which indeed will make this impossible, because when children's minds are in the formative period we shall have fixed in them through the medium of the schools, feelings of respect and friendliness for the other nations and peoples of the world. Dewey's emphasis, developed amid two World Wars, was on a sense of world patriotism and peaceful internationalism that would eliminate the horrific wars of his time, and his definition reflects that globalist theory. ${ }^{20}$

The highlight of Dewey's definition, developed amid two World Wars, is a sense of world patriotism and peaceful internationalism that would eliminate terrible wars, and it reflects that this is a globalist theory. So the curriculum in schools is developed to support world

19 T T Abebe, A Gbesso, and P A Nyawalo, "Report of the Working Committee Meeting on: Peace Education in Africa," Addis Abeba, Ethiopia: University for Peace. Retrieved December 6 (2006): 2013. 14

20 John Dewey, "The School as a Means of Developing a Social Consciousness and Social Ideals in Children," J. Soc. F. 1 (1923), 516. 
peace so that education implemented in schools is capable to remove hatred and suspicion to establish a sense of respect and friendliness for the people, nation, and all nations in the world, as Edward MoxonBrowne in his writings said that:

The word for 'peace' in the English language is derived from the Latin 'pax'. Peace in the Roman Empire meant a cessation in fighting as well as rule over subject races. A modern equivalent is found in definitions of peace through deterrence. This definition describes peace in terms of what it is not, rather than what it is. A child might graphically represent negative peace by first drawing a weapon of war, such as a rocket or bomb, and then placing a cross over it. A limitation of this approach is that although there may be an absence of armed hostility, the foundations for the next war may be dug. For example, militaristic attitudes, the build-up of weapons, the glorification of heroic conquests in history, and the use of enemy images or de-humanizing stereotypes in a text may provide fertile ground for even greater conflict in the future. ${ }^{21}$

The above definition provides a common example used in educational institutions today. Peace education is viewed in a holistic, interdisciplinary manner that seeks to improve knowledge, skills, values, and attitudes for peace itself. While, even though there is no single definition for peace education, this compilation shows that there are some various ways to define peace education as what $\mathrm{Nel}$ Noddings Emerita said:

Genuine education is aimed not merely at skills and a collection of facts - what Whitehead called "inert ideas" - but at a way of life that pursues understanding and an attitude of openness to new ideas and knowledge.1 This aim is acknowledged today by a verbal emphasis on critical thinking, but not much attention is given to what is meant by critical thinking or what might be done to advance it. Too often it means presenting students with an argument about which they are indifferent and asking them to evaluate it based on logical consistency, evidence offered and substantiated, and clarity of presentation. This is a useful exercise, but it is not adequate for

${ }^{21}$ Edward Moxon-Browne, "A Future for Peacekeeping?," in A Future for Peacekeeping? (Springer, 1998), 192-201. 
our purposes here. We have been talking about loving and hating war, and that means that the arguments to be considered arise in a strong emotional climate. ${ }^{22}$

In Western literature, the term peace education is not considered to be a new term, because some writers have discussed and developed ideas and actions to have a comprehensive definition of peace education. There are several definitions put forward about it, including the UNICEF version. The United Nations agency dealing with education defines peace education as the process of promoting the knowledge, skills, attitudes, and values needed to bring about behavioral change that enables children, youth, and adults to prevent conflict and violence; to resolve conflicts peacefully; and to create a conducive condition for peace, both at the interpersonal, interpersonal, intergroup, national, and international levels. ${ }^{23}$ Another view was expressed by Aghulor and Iwegbu who said that peace education is a program to establish the relevance of peace in citizens, both in the context of individual, community, and national life. ${ }^{24}$ Akbar Metrid in Imam Machali defines peace education as an educational model that seeks to empower the community to be able to overcome their conflicts in a creative and non-violent way. The values contained in peace education are mutual respect, love, fairness, justice, cooperation, and tolerance. ${ }^{25}$ Education is not just ingesting process but also a productive investment in society. ${ }^{26}$

22 Nel Noddings, Peace Education: How We Come to Love and Hate War (Cambridge University Press, 2011), 139.

${ }_{23}$ Susan Fountain, Peace Education in UNICEF (Unicef, Programme Division, 1999), 1.

24 Babatunde A Adeyemi and Mujidat O Salawudeen, "The Place of Indigenous Proverbs in Peace Education in Nigeria: Implications for Social Studies Curriculum," International Journal of Humanities and Social Science 4, no. 2 (2014), 186-92.

25 Imam Machali, "Peace Education Dan Deradikalisasi Agama," Jurnal Pendidikan Islam 2, no. 1 (2013), 41-64.

${ }^{26}$ Zaenal Abidin, "Pembangunan Pendidikan Perdamaian Dari Sekolah: Pendekatan Gerakan Sosial," Suhuf, 31, no. 2 (2019), 187-206. 


\section{History of Peace Education}

One of the first Europeans to use written work to support peace education was Comenius (1642/1969). ${ }^{27} \mathrm{He}$ was an educator in the Czech Republic who, in the seventeenth century, saw that shared universal knowledge (diversity) could give way to peace. The approach to peace assumes that understanding other people and shared values will overcome differences leading to the absence of conflict. The main goal of peace education is to create a world where men and women will live in harmony with the acceptance of cultural diversity. ${ }^{28}$ The development of peace education studies is in line with the growth of the peace movement. The modern peace movement against the war began in the nineteenth century after the Napoleonic wars when progressive intellectuals and politicians were formed.

By 1912 the School Peace League had branches in almost every state in the United States that promoted peace through schools of international justice and friendship. ${ }^{29}$ They have ambitious plans to introduce more than 500,000 teachers having a relatively new view of peace.

\section{Peaceful Education Transformation through Culture}

Transformative learning occurs when individuals change their frame of reference critically and have a belief that learners are aware of carrying out plans that bring new ways to their world. This can happen through critical thinking, where teachers can have dialogue and question and answer activities creatively with an emotional process. There is no single model in transformative learning, so students having different ways of learning may use different methods. Likewise, the approach taken by teachers is quite varied.

Transformative learning is very important to the peace education process. Peace education is a practice to change society from a culture of war to a culture of peace, the current worldview is embedded in the culture of war. Intelligence, behavior, and actions are influenced by that worldview. Therefore, transformative learning is the most

27 Ian M Harris, "Peace Education Theory," Journal of Peace Education 1, no. 1 (2002): 5-20.

28 Ian M Harris and Mary Lee Morrison, Peace Education (McFarland, 1999), 379.

29 David Scanlon, "Pioneers of International Education, 1817-1914," Teachers College Record 60, no. 4 (1959), 209-219. 
impo $\mathrm{r}$ t ant part of peace education. Five transformative peace educ at ions include five elements: Diversity, participatory learning, perspective, indigenous knowledge, and spiritual foundations.

The desire, hope, and need for peace are universal and transcend all a ges and spaces. Unfortunately, humans have never formed a clear culture of peace in which all people, without exception, can live peacefully. When you perceive culture as a way of life, then it suggests that a culture of peace means a peaceful way of life. The main challenge faced is how to build a global model of living in peace, where all people live peacefully with one another. Peace education seeks to address these challenges.

Peace Education can be defined broadly as an effort to educate as well as to create a culture of peace. A culture of peace integrates both negative and positive concepts of peace and involves the transformation of society from a culture of war and violence to a culture of peace and non-violence one. The peace culture models include floral and integral models.

First, the model of interest in a culture of peace was developed by Virginia Cawagas and Swee Hin Toh. Toh was a recipient of the UNESCO Prize for peace education in 2000. This model has shaped a culture including (1) dismantling the culture of war; (2) stating human rights and responsibilities; (3) life, justice, and compassion; (4) Culture of building respect, reconciliation, and solidarity; (5) living in harmony, and (6) a culture of inner peace. ${ }^{30}$

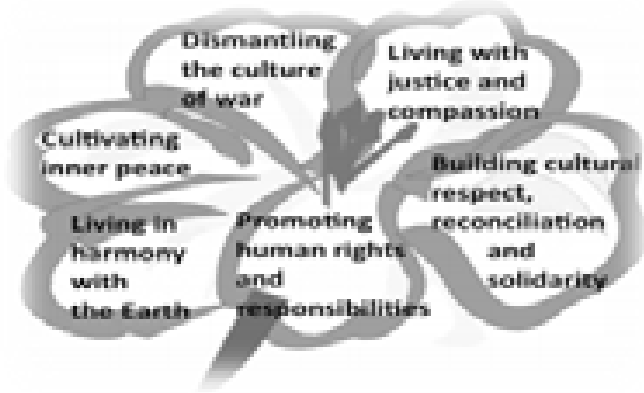

Figure 2.1. Flower Model (Toh dan Cawagas)

Second, the Integral model for peace education was

${ }^{30}$ Swee Hin Toh and V F Cawagas, "A Holistic Understanding of a Culture of Peace" (APCEIU Expert Consultation on EIU, Fiji, 2002). A Holistic Understanding of a Culture of Peace. Presented at the APCEIU Expert Consultation on EIU, Fiji. 
developed by the University for Peace and the Central American government during the first phase of the peace culture and democracy program. The Integral Model is a mandala-shaped, framework-centered, which combines the context of peace with oneself, others, and nature, at the ethical, mental, emotional, and activity levels. ${ }^{31}$

\section{Peace Education in Islam}

The word 'Islam' originates from Arabic which has several meanings, Islam is the root word from aslama-yuslimu-salaman which means submission or surrender compliance and obedience or giving in. it means that everything, both knowledge, attitudes, behavior, and lifestyle shows submission and obedience to Allah's will is Islam and the essence of submission to Allah Swt., is absolute, unanimous and total. ${ }^{32}$

Islam is a collection of rules created to attract and guide intelligent people to submit and conform to righteousness so that they can get happiness in the world and the hereafter. ${ }^{33}$ Humans who have been given intellectual and desire are trusted by God to become caliphs having the mission of protecting the earth from any destruction. Its function is to be a balance between the two powers possessed by humans. Religion is the answer. Islam always teaches its people to respect each other, make peace without jealousy and revenge, because Islam is a religion of nature, and human nature prefers a sense of peace, mutual love between humans, mutual respect between religious communities, and mutual help.

Peace has several meanings. The sense of the meaning of peace changes according to its relationship to the sentence. Peace can refer to an agreement to end war or the absence of war, or to a period in which an armed force is not fighting an enemy. Peace can also mean a state of calm. Everyone's conception of peace is different according to their culture and environment. People from different cultures sometimes

31 Abelardo Brenes-Castro, "An Integral Model of Peace Education," Educating for a Culture of Social and Ecological Peace, 2004, 77-98.

32 Assegaf Abdurrahman, Pendidikan Tanpa Kekerasan (Yogyakarta: Tiara Wacana, 2004), 47-179.

33 M Hasbi Ash Shiddieqy, Al-Islam (Bandung: Bulan Bintang, 1956), 49. 
disagree with the sense meaning of the word itself, and so do people in a particular culture. Peace is seen as a basic or superior thing in Islam. Islam is a blessing brought by the Prophet Muhammad. Therefore, Islam commands us to always be balanced in everything including in socializing, neither confirming absolutely nor blaming absolutely towards any arguments. Peace is the unity of people and nations. We are decreed to always be at peace with each other, establishing $u k h u w a h$ without any barriers and limitations in it. Hence, Allah sent His messengers to spread teachings that can be a lantern for humans to navigate this ark of life. Islam is a perfection of the previous teachings. Islam is the last heavenly religion brought by the last messenger and for the last people living in the last days. By referring to the Qur'an and Sunnah, Islam can answer the challenges of the times since its emergence in this era, and even to the future. ${ }^{34}$

There are several ways to establish peace in the teachings of Islam so that they can live in prosperity and harmony, including:

a. Prohibition of Wrongdoing

Islam as a religion that carries a mission of peace strictly forbids mankind to do injustice, anytime and anywhere. As Allah says: "And whoever among you does wrong, We will surely feel for him a great punishment". ${ }^{35}$ Wrongdoing is a source of disaster that can undermine the stability of world peace. The oppression, torture, destruction, expulsion, modern imperialism that often occurs in Muslim countries today has resulted in a global reaction against these depraved acts in various ways, so that peace is increasingly difficult to achieve. So every human being should be aware that injustice is the cause of setbacks. Thus, if you want a peaceful life, then acts of tyranny must be avoided, equality between humans is one of the things that is emphasized in Islam. There is no difference between one group and another. All have the same rights and obligations whether you are rich or poor.

b. Impartial Equality

Officials, employees, differences in skin, ethnicity, and language are not reasons to favor one group over other groups. Allah says: "O, mankind, indeed We created you from a male and a female

${ }^{34}$ Muhammad Abdulbasir Khadiri, Muqaddimah fi al-Nudzum al-Islamiyah (tk: tp, 2003), 91.

35 QS. Al-Furqan: 19. 
and made you into nations and tribes so that you may know one another. Verily, the most honorable of you in the sight of Allah is the most pious of you. Verily Allah is All-Knowing, All-Eloquent (QS. al-Hujurat: 13). ${ }^{36}$

So what distinguishes one's degree over another is only the piousness. The most pious is the noblest. With this equality, it will minimize the emergence of the seeds of hatred and enmity between humans, so that all can live in harmony and peace.

c. Upholding Justice

Islam emphasizes peace in social life within the society, justice must be applied to anyone even with enemies. Because of the enforcement of justice, then no one feels let down and discriminated against to reduce the feeling of hostility, thus conflict will not occur.

Allah says in the Qur'an, "O you who believe, let you be those who always uphold (the truth) for the sake of Allah, bear witness with justice. And don't let your hatred of a people encourage you to act unjustly. Be fair, because it is closer to godfearing. And fear Allah, indeed Allah is Knowing of what you do. (QS. al-Maidah: 8). ${ }^{37}$

This verse is a strong indication that the message of the prophet Muhammad Saw. is very noble because his teachings can save people from the destruction caused by lust and the whispers of Satan.

d. Giving Freedom

Islam values freedom. This is proven by the absence of coercion for anyone in religion, everyone is free to make his choice. His Word: There is no compulsion to accept the religion (Islam); Indeed, the right path is clear from the wrong path. ${ }^{38}$

Give others the freedom to express their opinions to create justice. ${ }^{39}$ With this freedom, everyone will be satisfied to make their choice. No individual feels constrained to the point that it leads to hatred. With this freedom, the path to a peaceful life is wide open.

e. Promoting a Harmonious Life and Helping Each Other

36 Departemen Agama RI, Al-Qur'an Dan Terjemahnya Al-Jumanatul 'Ali (Bandung: CV. Penerbit J-ART, 2005), 518.

37 Ibid., 108.

38 QS. al-Baqarah: 256

39 Alwi Shihab, Nilai-Nilai Pluralisme Dalam Islam: Bingkai Gagasan Yang Berserak, ed. Sururin, 2005, 21. 
Islam also promotes living in harmony with mankind, helping each other in doing noble deeds, and invites them to work hand in hand to terminate the injustice on this earth, with the hope that a peaceful and prosperous life can be realized.

Within human interaction, the act of love has a high place in the heart. The presence of compassion lightens incites to do a good thing, and cheers the heart, increases the interest and influences towards good attitudes and creates a sense of sympathy, and feels what others feel. ${ }^{40}$

f. Encouraging Tolerance

Islam encourages its people to be tolerant of each other despite all differences. The aim is to prevent disputes that can harm all parties. In His word, "And is not the same as good and evil. Reject (the evil) in a better way, then suddenly the person between you and between him there is enmity as if he has become a very loyal friend. These good qualities are not bestowed on those who are patient, and they are not given but to those who have great fortune" (QS. Fushshilat: 34-35). ${ }^{41}$

g. Fostering Social Solidarity

Social solidarity is also emphasized by this noble religion to be instilled in every individual in society to posture humans in their place and to eradicate poverty, ignorance, and uncertain life. Islam requires people who can afford to set aside their wealth to be given to those in need.

\section{PLANNING STAGE FOR PEACE EDUCATION AT NURUL ISLAM ISLAMIC BOARDING SCHOOL IN JEMBER}

Setting up the curriculum and learning requires good planning, as well as the planning stage for the curriculum, and peace learning requires some preliminary acts before the planning is carried out. Conceptually James A.F. Stoner formulated four steps in the planning stage. ${ }^{42}$ These four planning steps can be adapted to all planning-type activities at all levels of the organization. The four steps are establishing goals or a

40 Ahmad D Marimba, Pengantar Filsafat Pendidikan Islam (Penerbit Alma' Arif, 1964).

41 Departemen Agama RI, Al-Qur'an Dan Terjemahnya Al-Jumanatul 'Ali, 480.

42 James A F Stoner and Charles Wankel, "Perencanaan \& Pengambilan Keputusan Dalam Manajemen 1,” 1993, 128-29. 
set of goals, defining the current situation, identifying things that help and hinder the objectives or goals, both internally and externally, and developing a plan or set of actions to achieve the goals.

Planning stages, according to A.F. Stoner, are tested in certain environments and situations, but the concept of A.F. Stoner had to be the one that adapts to different environments and situations. Based on the identifying process within the planning concept of A.F. Stoner, the results of the research shows that the concept is not necessarily applicable to different situations and conditions, which means that there are some factors behind the inhibition of existing planning, or even new findings from the planning concept in subsequent of the research findings. Based on the research results using the analysis of the planning concept of A.F. Stoner, it points out that the planning stage of peace education includes: first, the planning of peace education is based on the principles of Islamic Wasathiyah practice (moderate), the philosophy within the name of the Islamic boarding school, the vision and mission of the Islamic boarding school which based on the books of the ulama' mazhab asy'ariyah and the works of Islamic scholars within the archipelago. Second, the planning of peace education is preceded by a need analysis of the current times, the community, and the personal needs of students, as well as paying attention to input from the guardians of students, alumni, and sympathizers. Third, peace education planning is formulated directly by the foundations and institutions under its auspices.

\section{IMPLEMENTATION STAGE OF PEACE EDUCATION AT NURUL ISLAM ISLAMIC BOARDING SCHOOL IN JEMBER}

Peace education is quite important to be taught in pesantren for it is infused within the concepts of Islam rahmat li al-'alamin which include: the concept of tasamuh or tolerance, and plurality in religion. Moreover, according to Magnis-Suseno, some of the recognized human values, which are fundamentally accepted by every human being and every religious community, have not been distorted ideologicallyfundamentally. These values comprise insights that everyone's life is sacred; people should not be tortured and their lives should not be ruined; we do not insult and do not hurt others; conflicting opinion and interests must be resolved fairly and peacefully without resorting 
violence; every group of people must be respected related to their identity which includes what is believed to be true (the essence of religious independence); people should not be forced to do something that they consider evil (the essence of independent conscience); people should not be left in poverty and suffering state (solidarity towards the oppressed poor), the diversity of cultural expressions must be respected, promoting tolerance for other peoples' eccentricities (as long as it is not threatening); the act of lies, deception, corruption will never be true as well as under no circumstances cruelty is justified; people should be treated fairly and humanely without being discriminated based on their gender, religious, and political beliefs, race, cultural characteristics and social standing. ${ }^{43}$

Pesantren education is an educational model organized aiming for teaching the basic concepts of Islam. Such an educational institution does not generate any Civil Servants willing to be ordered by others. Pesantren is also seen as an educational institution that produces independent people capable of doing anything on their own..$^{44}$ Looking back, pesantren education is based on peace education, because when it is carefully examined Islamic boarding school education aims to achieve what is called worldly and divine hasanah. These two entities are the important essence of pesantren education, therefore pesantren focuses on peace.

Pesantren-based peace education emphasizes the characteristics of peace itself consisting of: (1) peace is dynamic; (2) peace is a problem solving without upholding violence; (3) peace produces balance in social interactions so that humans live in harmonious relationships; (4) peace is good for society; (5) there will be no peace when violence is around; (6) to promote a balance in the dynamics of social interaction, peace must stand on justice and freedom; (7) to sustain injustice and restriction, peace is nowhere to be found. ${ }^{45}$

In the current era, the educational model implemented at Nurul Islam Islamic Boarding School and Al-Qodiri Islamic Boarding

43 Frans Magnis Suseno, "Mendidik Bangsa Untuk Mau Berdamai: Agar Negara Kita Betul-Betul Bersatu," in Makalah Pada Seminar Nasional Dan Diskusi Panel Pendidikan Damai, Universitas Negeri Malang, Vol. 22, 2008.

44 Suparlan Soeryo Pratondo and M Syarif, Kapita Selekta Pondok Pesantren (Jakarta: Paryu Barkah, 2007), 171.

45 Suparno, "Pendidikan Damai", Makalah pada Seminar Nasional dan Diskusi Panel Pendidikan Damai, Universitas Negeri Malang, Malang, 22 Desember 2008. 
School is a contextualization of typical pesantren learning materials with contemporary issues (temporary humanity issues) such as multiculturalism, gender, and counter-radicalism. Islamic learning material which usually revolves around the study of classical texts now seems to begin being characterized as more down to earth, such as being integrated into the study of humanitarian issues, human rights, gender, human trafficking, global warming, ecology, technological progress, and the dynamics of others humanitarian issues. Peace education is an effort made to realize values, behaviors, and ways of life that support the creation of a peaceful culture. According to Eneng Muslihah, the purpose of peace education is to provide understanding and awareness of the roots within the conflict, violence, and non-peace deeds in the personal, interpersonal, community, national, regional, and international domain. ${ }^{46}$

Peace education has become an urgent agenda for several reasons. First, peace education can be the most effective instrument for trauma recovery. Second, peace education is important because the students are enabled to understand strategies to deal with and even how to resolve conflicts and problems. Third, peace education is important to be taught to the younger generation for they are considered to be the backbone of sustainable peace development. The peace movement is very significant in a way it is seen as an important part of peace education. ${ }^{47}$

Substantially, peace education taught to santri has three characteristics which include: knowledge/understanding; ability/ expertise (skill/competencies), and attitude/value. These three characteristics are synergistically shown in the triangle (knowledgeskill-attitude). ${ }^{48}$ In this behavior changing process, the following stages are carried out continuously: (1) Making peace and conflict issues as a shared awareness; (2) Making peace and conflict issues as a common concern; (3) Gaining understanding and skills related

46 Eneng Muslihah, "Pesantren Dan Pengembangan Pendidikan Perdamaian Studi Kasus Di Pesantren An-Nidzomiyyah Labuan Pandeglang Banten," ANALISIS: Jurnal Studi Keislaman 14, no. 2 (2014), 311-340.

47 Laksiri Fernando, Peace Studies Dalam Conflict Resolution I\& Peace Studies An Introductory Handbook (Center for Policy Research and Analysis (CEPRA): University of Colombo, 2000), 46.

48 Ellie Ken and Anca Tirca, "Education for Democratic Citizenship," Apredo, Rumania, 1999, 13. 
to the issue; (4) establishing motivation based on new attitudes and values; (5) encouraging desire to act; (6) endeavoring new behaviors such as peaceful conflict resolution; (7) Evaluating such experience; (8) Practicing the recommended behavior. ${ }^{49}$

\section{THE IMPLICATIONS OF PEACE EDUCATION ON THE ATTITUDES AND BEHAVIOR OF SANTRI}

Islamic boarding schools or Pesantren as educational institutions are characterized by the culture of Nusantara based on the teachings from Walisongo's preaching. Islamic boarding schools develop education by teaching about the basic concepts of Islam and the studies of the Kitab Kuning. Pesantren is also an educational institution that produces students as agents of change in society by promoting the preaching and being independent based on the objectives of the establishment of Islamic boarding school itself in Indonesia. ${ }^{50}$ As the results of Muammar Ramadhan's research, regarding the history of the development of Islamic boarding schools, where pesantren are seen as educational institutions that are moderate and accommodating to the differences that exist in society so that pesantren are transformed into education that develops a local wisdom education system with community empowerment strategies according to their conditions as what being implemented at Nurul Islam Islamic Boarding School Jember. ${ }^{51}$ From the results of the research, these two Islamic boarding schools are the ones that develop the concept of Nahdatul Ulama (NU)based teaching having the concepts of tasāmuh, tawassuth, tawāzun, and i'tidal which become counseling and guidance's principles to students in everything they do. From this standing point, the researcher saw how the role of these two Islamic boarding schools in providing peaceful education within the pesantren educational system. This is clear evidence that Islamic boarding schools are institutions that foster

49 Fountain, Peace Education in UNICEF. 5

50 M Imam Zamroni, "Islam, Pesantren, Dan Terorisme," Jurnal Pendidikan Agama Islam 2, no. 2 (2005), 177-194.

51 Muammar Ramadhan, "Deradikalisasi Agama Melalui Pendidikan Multikultural Dan Inklusivisme (Studi Pada Pesantren Al-Hikmah Benda Sirampog Brebes)," Jurnal SMART (Studi Masyarakat, Religi, Dan Tradisi) 1, no. 2 (2015). 
peace values in social and religious life as well as it is perceived as anti-violence institution. ${ }^{52}$

From the explanation above, there are several implications for peace education implementation at Nurul Islam Islamic boarding school; first, students have polite and tolerant behavior towards anyone; second, having a moderate education pattern, the students develop a moderate and contextual perspective; third, the Sufistic behavior of students is getting better at the Islamic boarding school; fourth, it promotes a positive image within national and regional local communities; fifth, an emerging institutional transformation.

\section{CONCLUSION}

The model of integrative peace education based on contextual Islamic washatiyah at Nurul Islam Islamic Boarding School Jember starts from; first, the planning stage of pesantren's peace education which refers to the vision, mission, the institutional philosophy, and principles of Islamic washatiyah (moderate) practice, preceded by a need analysis of the current times, the social community, students, and paying attention to input from educational services users and formulated by educational foundations. Second, the implementation of peace education in Islamic boarding schools adapts the learning material from religious texts with a moderation approach, implementing Islamic methods and universal methods, applying media supporting websites with digital content of washatiyah literacy and digital Sufism literacy carried out informal institutions with a pattern of the integration of aswaja-based teachings both through class-based intra-curricular activities as well as extracurricular intensively and doctrinally in Islamic boarding schools. Third, the implications of Islamic boarding school peace education are to form polite and tolerant attitudes, a moderate and contextual perspective, shape the Sufistic attitude of the students, form a positive image for local, national, and regional communities as well as encourage the transformation of pesantren institutions sustainably. The theoretical implication of this research on the theory of curriculum and learning management is within the theory developed by Jemes A.F. Stoner about the four steps in the planning process, such as setting goals, defining the current situation, identifying things that

52 Marzuki Wahid and others, Pesantren Masa Depan (Bandung: Pustaka Hidayah, 1999), 16. 
help and hinder the organization's goals, development of plans or courses of action to achieve goals. Based on the research findings, the planning stage of Islamic boarding school for peace education refers to the vision, mission, institutional philosophy, and the principle of Islamic washatiyah practice (moderate), proceeded by a need analysis of the times, the social community and students, as well as paying attention to input from educational services users and formulated by educational foundations.

\section{REFERENCES}

Abdurrahman, Assegaf. Pendidikan Tanpa Kekerasan. Yogyakarta: Tiara Wacana, 2004.

Abebe, T T, A Gbesso, and P A Nyawalo. "Report of the Working Committee Meeting on: Peace Education in Africa." Addis Abeba, Ethiopia: University for Peace. Retrieved December 6 (2006): 2013.

Abidin, Zaenal. "Pembangunan Pendidikan Perdamaian Dari Sekolah: Pendekatan Gerakan Sosial.” Suhuf, 31, no. 2 (2019): 187-206.

Adeyemi, Babatunde A, and Mujidat O Salawudeen. "The Place of Indigenous Proverbs in Peace Education in Nigeria: Implications for Social Studies Curriculum." International Journal of Humanities and Social Science 4, no. 2 (2014): 186-92.

Ali, Mohammad Daud, and Habibah Daud. Lembaga-Lembaga Islam Di Indonesia, Cet. 1 (Jakarta: PT. Raja Grafindo Persada), 1995.

Bafadal, Ibrahim, and Masykuri Bakri. Metodologi Penelitian Kualitatif: Tinjauan Teoritis Dan Praktis. Malang: Lemlit Unisma Dan Visipress, 2013.

Brenes-Castro, Abelardo. "An Integral Model of Peace Education." Educating for a Culture of Social and Ecological Peace, 2004, 77-98.

Data Profil Pondok pesantren Nurul Islam (NURIS) Jember 2020. 
Departemen Agama, R I. Al-Qur'an Dan Terjemahnya Al-Jumanatul 'Ali. Bandung: CV. Penerbit J-ART, 2005.

Dewey, John. "The School as a Means of Developing a Social Consciousness and Social Ideals in Children." J. Soc. F. 1 (1923): 513.

Dhofier, Zamakhsyari. Tradisi Pesantren, Studi Tentang Pandangan Hidup Kyai. Jakarta: LP3ES.” Indonesia, 1990.

Fernando, Laksiri. Peace Studies Dalam Conflict Resolution \& Peace Studies An Introductory Handbook. Center for Policy Research and Analysis (CEPRA). University of Colombo, 2000.

Fountain, Susan. Peace Education in UNICEF. Unicef, Programme Division, 1999.

Ghazali, M Bahri. Pesantren Berwawasan Lingkungan. Prasasti, 2002.

Habiby, Wahdan N, and others. "Penyemaian Sikap Hidup Damai Di Sekolah: Tinjauan Pendidikan Perdamaian Dan Multi-Dimensi Kurikulum." Scholaria: Jurnal Pendidikan Dan Kebudayaan, 2020, 1-11.

Harris, Ian M. "Peace Education Theory." Journal of Peace Education 1, no. 1 (2002): 5-20.

Harris, Ian M, and Mary Lee Morrison. Peace Education. McFarland, 1999.

Hendry, Eka. "Pengarusu Utamaan Pendidikan Damai (Peaceful Education) Dalam Pendidikan Agama Islam (Solusi Alternatif Upaya Deradikalisasi Pandangan Agama)." At-Turats: Jurnal Pemikiran Pendidikan, 2015.

Jamaluddin, Malik. Pemberdayaan Pesantren: Menuju Kemandirian Dan Profesionalisme Santri Dengan Metode Daurah Kebudayaan.Yogyakarta: Pustaka Pesantren Dan Yayasan Kantara Bangsa, 2005.

Kaeuper, Richard W. Holy Warriors: The Religious Ideology of Chivalry. University of Pennsylvania Press, 2009. 
Ken, Ellie, and Anca Tirca. "Education for Democratic Citizenship." Apredo, Rumania, 1999.

Khadiri, Muhammad Abdulbasir. Muqaddimah fi al-Nudzum alIslamiyah, 2003.

Lukens-Bull, Ronald. A Peaceful Jihad: Negotiating Identity and Modernity in Muslim Java. Springer, 2005.

Machali, Imam. "Peace Education Dan Deradikalisasi Agama." Jurnal Pendidikan Islam 2, no. 1 (2013): 41-64.

Makdisi, George. Rise of Humanism in Classical Islam and the Christian West. Edinburgh University Press, 1990.

Marimba, Ahmad D. Pengantar Filsafat Pendidikan Islam. Penerbit Alma Arif, 1964.

Mastuhu. Dinamika Sistem Pendidikan Pesantren: Suatu Kajian Tentang Unsur Dan Nilai Sistem Pendidikan Pesantren. INIS, 1994.

Moxon-Browne, Edward. “A Future for Peacekeeping?” In A Future for Peacekeeping?, 192-201. Springer, 1998.

Muslihah, Eneng. "Pesantren Dan Pengembangan Pendidikan Perdamaian Studi Kasus Di Pesantren An-Nidzomiyyah Labuan Pandeglang Banten.” ANALISIS: Jurnal Studi Keislaman 14, no. 2 (2014): 311-40.

Noddings, Nel. Peace Education: How We Come to Love and Hate War. Cambridge University Press, 2011.

Nuryanto, M. Agus. "Isu-isu Kritis dalam Pendidikan" dalam Nizar Ali dan Sumedi, Antologi Pendidikan Islam. Program Studi Pendidikan Islam Pascasarjana UIN Sunan Kalijaga \& Idea Press, 2010.

Nuryatno, M Agus. Mazhab Pendidikan Kritis: Menyingkap Relasi Pengetahuan, Politik, Dan Kekuasaan. Resist Book, 2008.

Pratondo, Suparlan Soeryo, and M Syarif. Kapita Selekta Pondok Pesantren. Jakarta: Paryu Barkah, 2007.

Qomar, Mujamil. Pesantren: Dari Transformasi Metodologi Menuju Demokratisasi Institusi. Erlangga, 2009. 
Ramadhan, Muammar. "Deradikalisasi Agama Melalui Pendidikan Multikultural Dan Inklusivisme (Studi Pada Pesantren Al-Hikmah Benda Sirampog Brebes)." Jurnal SMART (Studi Masyarakat, Religi, Dan Tradisi) 1, no. 2 (2015).

Scanlon, David. "Pioneers of International Education, 1817-1914."

Teachers College Record 60, no. 4 (1959): 209-19.

Shiddieqy, M Hasbi Ash. Al-Islam. Bandung: Bulan Bintang, 1956.

Shihab, Alwi. Nilai-Nilai Pluralisme Dalam Islam: Bingkai Gagasan Yang Berserak". ed. Sururin, 2005.

Stoner, James A F, and Charles Wankel. "Perencanaan $\backslash \&$ Pengambilan Keputusan Dalam Manajemen 1," 1993.

Sugara, Robi. “Upaya Dan Kontribusi Indonesia Dalam Proses Perdamaian Di Afghanistan Melalui Bina-Damai." MUKADIMAH: Jurnal Pendidikan, Sejarah, Dan Ilmu-Ilmu Sosial 5, no. 1 (2021): 27-38.

Suparno, "Pendidikan Damai", Makalah pada Seminar Nasional dan Diskusi Panel Pendidikan Damai, Universitas Negeri Malang, Malang, 22 Desember 2008.

Suseno, Frans Magnis. "Mendidik Bangsa Untuk Mau Berdamai: Agar Negara Kita Betul-Betul Bersatu." In Makalah Pada Seminar Nasional Dan Diskusi Panel Pendidikan Damai, Universitas Negeri Malang, Vol. 22, 2008.

Toh, Swee Hin, and V F Cawagas. "A Holistic Understanding of a Culture of Peace.” APCEIU Expert Consultation on EIU, Fiji, 2002.

Wahab, Abdul, and Lies Amin Lestari. Menulis Karya Ilmiah. Surabaya: Airlangga University Press, 1999.

Wahid, Marzuki, and others. Pesantren Masa Depan. Bandung: Pustaka Hidayah, 1999.

Yin, Robert K. Case Study Research: Design and Methods. Vol. 5. sage, 2008 .

Zamroni, M Imam. "Islam, Pesantren, Dan Terorisme." Jurnal Pendidikan Agama Islam 2, no. 2 (2005): 177-94. 